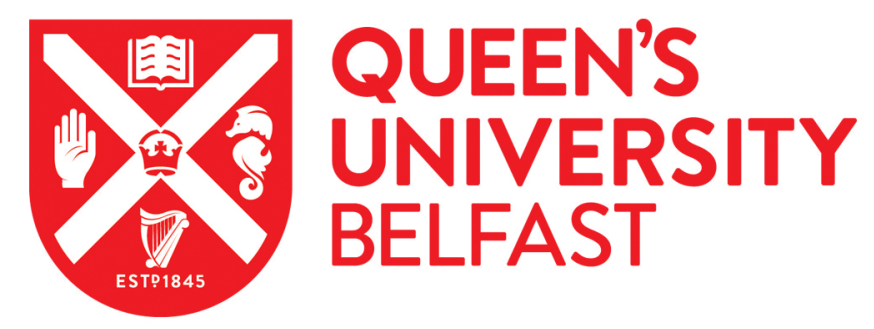

\title{
Young Men Doing Business: Male Bar Prostitution in Berlin and Prague
}

Ellison, G., \& Weitzer, R. (2017). Young Men Doing Business: Male Bar Prostitution in Berlin and Prague. Sexualities, 21(8), 1389-1408. https://doi.org/10.1177/1363460717708139

\section{Published in:}

Sexualities

\section{Document Version:}

Peer reviewed version

Queen's University Belfast - Research Portal:

Link to publication record in Queen's University Belfast Research Portal

Publisher rights

Copyright 2018 SAGE. This work is made available online in accordance with the publisher's policies. Please refer to any applicable terms of use of the publisher.

\section{General rights}

Copyright for the publications made accessible via the Queen's University Belfast Research Portal is retained by the author(s) and / or other copyright owners and it is a condition of accessing these publications that users recognise and abide by the legal requirements associated with these rights.

Take down policy

The Research Portal is Queen's institutional repository that provides access to Queen's research output. Every effort has been made to ensure that content in the Research Portal does not infringe any person's rights, or applicable UK laws. If you discover content in the Research Portal that you believe breaches copyright or violates any law, please contact openaccess@qub.ac.uk. 


\title{
Young men doing business: Male bar prostitution in Berlin and Prague
}

Published in Sexualities, 2017, Vol. 21(8) 1389-1408.

\section{Graham Ellison}

Queen's University Belfast, UK

\section{Ronald Weitzer}

George Washington University, USA

\begin{abstract}
Studies of male sex workers are often confined to the individual level rather than exploring their work environment per se or the larger ecological context in which their business activities are embedded. We know relatively little, for example, about the spatial location of erotic worksites (apart from street-level work) or the interactional dynamics of sellers and clients within such settings. This paper presents an ethnographic study of bars and clubs in Prague and Berlin where male sexual commerce is transacted. We find important differences between the cities in the social organisation of the bars and in participants' demographic characteristics. The analysis links our micro-level findings to the larger forces of labour migration and sex tourism, factors that differ between the two cases.
\end{abstract}

\section{Keywords}

male sex work, bar prostitution, social ecology, sex tourism, labour migration

\section{Corresponding author:}

Graham Ellison, Institute of Criminology and Criminal Justice, School of Law, Queen's University, Belfast BT7 1NN, Northern Ireland, UK.

Email: g.ellison@qub.ac.uk 
Research on sex work has focused on female workers to a far greater extent than their male counterparts, despite the fact that male sex work comprises a substantial proportion of the market and is key to elucidating the impact of gender in shaping sex workers' experiences and other outcomes. A review of 166 academic articles on sex work found that only one-tenth focused on male providers (Dennis 2008), and the literature on male sex workers (MSWs) is itself deficient in certain respects. One limitation is that most studies of MSWs research them outside their work contexts (i.e., street, park, bar, sauna, escort agency) rather than situating them within those settings or focusing on the site in its own right (exceptions include Atkins and Laing, 2012; Ellison and Weitzer, 2016; Padilla, 2007; Pittman, 1971; Salamon, 1989; Smith, Grov, and Seal, 2008; Takeyama, 2005). And some studies that purport to be contextual report few findings on ecological, organisational, or interactional aspects, and instead focus on workers' demographics or decontextualized experiences (Storer, 1999; Schifter and Aggleton, 1999). This paper reports findings from an ethnographic study of male bar prostitution in Berlin and Prague, where the bar sector represents a significant part of the topography of male commercial sex in each city. While the bars in each jurisdiction share some basic similarities - as places where MSWs transact business with clients - we also find important city-level differences in their social ecology and their internal social organisation. We document both similarities and differences across the settings and link these patterns to larger processes of labour migration and sex tourism.

\section{Male bar prostitution}

Sex work is stratified by location, and the literature points to both similarities and important differences between male and female sex workers in each of these echelons: street, bar, brothel, escort agency, and Internet-based. Like female street sellers, males on the street often come from abusive families, are runaways, have a history of foster care or homelessness, use addictive drugs, 
and sell sex out of economic destitution (Calhoun and Weaver, 1996; Davies and Feldman, 1999; El-Bassel, 2000; Lankenau et al., 2005). And like mid- and upper-level female workers, males working in bars, brothels, and as escorts typically possess social skills that allow them to relate to their clients; many offer a "boyfriend experience" involving meaningful discourse and intimate sharing in addition to sex (Smith, Grov, and Seal, 2008; Koken, Bimbi, and Parsons, 2010). Male and female providers working in these sectors are more likely than street workers to hold positive views of their work and themselves (Aggleton, 1999; Minichiello, 2001; Uy et al., 2007; West, 1993).

Many MSWs operate from bars and sauna clubs. Such businesses may be dispersed or clustered in a particular area of a city, with varying effects on the surrounding community. The literature offers mixed findings regarding the ecological impact of erotic businesses, whether isolated or clustered in red-light districts. Some of these sites have adverse effects on the surrounding community's quality of life and crime rate, while others have no appreciable community impact (Linz, 2004; Prior and Crofts, 2012; Weitzer, 2012, 2014; Weitzer and Boels, 2015). One of the cities in the present study contains a small red-light district consisting of bars where MSWs operate, whereas in the other city these bars are geographically dispersed.

Studies of bar prostitution are relatively scarce, but the extant research suggests that this type of sex work takes two main forms:

(1) owner-managed, with three subtypes: (a) sex workers are directly employed by the owner (perhaps doubling as waiters or waitresses), (b) sex workers are freelance operators who are obliged to pay the owner a portion of their earnings, or (c) the client pays the bar owner a fee in order to take a worker out of the bar for sexual activities at a hotel or residence.

(2) owner-allowed: the bar serves as an arena in which independent workers solicit clients. The bar staff neither manage nor are directly compensated for providing a place where 
sexual transactions are arranged. These bars profit indirectly by virtue of customers buying drinks or paying a cover charge. Without sex workers on the premises the bar's income would be significantly lower or insufficient to sustain the enterprise.

Bar prostitution varies in other ways as well: whether the bar allows sex on the premises; whether staff members actively facilitate sexual transactions; and in the interactional dynamics among workers (competitive, collegial, or indifferent) and between workers and patrons (relaxed, socializing atmosphere or pressured, time-sensitive solicitation). Each type is represented in both male and female worksites (e.g., Darley, 2009; De Lind van Wijngaarden, 1999; Kishindo, 1995; Steinfatt, 2002; Storer, 1999; Takeyama, 2005; Trotter, 2008; Zheng, 2009).

The bars in the current study fit the second type. MSWs solicit other men in these bars with the blessing of owners, and a substantial proportion of the owners' income is due to the patronage of clients of the sex workers who operate therein. Nevertheless, while the bars in both cities provide a Type 2 venue, our findings reveal substantial variation in how these bars operate in each city and particularly in terms of their social organisation and the demographics of MSWs and clients. The situation in Prague is also complicated by a greater variation among the bars with different establishments catering to a range of client tastes and preferences.

It is important to emphasise that each city's bar scene is shaped by external dynamics. For Prague, an important external dimension is its robust sex tourism. Although most of the research on sex tourism centres on female providers and foreign male clients, sex tourism also takes place between men (e.g., Bunzl, 2000; Mendoza, 2013; Mitchell, 2011; Padilla, 2007). Since the late 1990s, Prague has attracted large numbers of foreign men from the US, UK, and Germany, seeking sexual encounters with younger Czech males. Male sex tourism is much less evident in Berlin's MSW bars, where most of the customers are German nationals. A second important external dynamic is labour migration. In Berlin most bar-based MSWs are external migrants from countries such as Bulgaria and Romania. Conversely, this external migration is much less 
noticeable in Prague where such MSWs tend to be internal migrants from outlying and economically underdeveloped parts of the Czech Republic, although a few do migrate from neighbouring Slovakia. Our analysis examines the role of these external dynamics in shaping both the bars' internal organisation and participants' interactional patterns.

\section{Research methods}

The findings presented here are based on ethnographic research conducted in 2013 . The study was funded by a research grant from the British Academy / Leverhulme Trust and was approved by the ethics committees at the researchers' universities. ${ }^{1}$ We began by identifying all bars where MSWs operate, locating eight bars in the two cities. In the first stage of data collection, we diagrammed each bar's location within the city, noted the physical conditions of the surrounding area, and recorded descriptions of each bar's interior arrangements. In the second stage, we (1) conducted observations inside the bars, (2) engaged in conversations with MSWs and customers, (3) interviewed bar managers and owners, and (4) interviewed senior staff at two NGOs that conduct outreach work with MSWs. A German and a Czech research assistant were employed to assist with making contacts with potential respondents and to provide translation services during the interviews if required. Observational data were recorded in fieldnotes (after leaving a bar) and formal interviews were digitally recorded with the respondent's permission. Language issues were a problem when speaking to some MSWs in Berlin, where few migrant sex workers spoke English or German. ${ }^{2}$ Most MSWs in Prague spoke English and some did so with

\footnotetext{
${ }^{1}$ Funding for the research on which this paper is based was provided by the British Academy/Leverhulme Trust via their Small Research Grant Scheme (grant number: SG122449).
}

\footnotetext{
2 A Romanian MSW stated that many Roma sex workers in Berlin spoke para-Romani dialects rather than Romanian, which made it even more difficult for them to converse with other-language speakers.
} 
considerable fluency. Bar managers in Berlin were happy to converse in English and two of the owners / managers in Prague spoke only English since they originally hailed from the UK and the US.

We assumed the role of bar customers in our observations at each bar. We would order a drink, take note of the physical layout, observe and discuss others' interactions (to facilitate recall for later recording in fieldnotes), and occasionally interact with others in the establishment. The status of the researchers as middle-aged white males from the UK and the US meant that we were able to blend inconspicuously into each bar as we matched the demographic profile of patrons in both cities. As a result of our backgrounds and fairly passive presence in the bars our presence did not alter the settings' interactional dynamics. We were able to blend in and casually engaged in observations and interactions with others. However, we did manage to speak to a small number of MSWs in each jurisdiction, inquiring about basic demographic information, their reasons for coming to Berlin or Prague and so forth. In these instances we disclosed our role as researchers and this did not appear to affect their engagement with us.

Throughout the paper we identify (with permission) the organisations that provide services to the sex workers, but use pseudonyms for all other individuals and bars. While the conversations with MSWs and some clients provided key information on their backgrounds, experiences, and the bar scene, our interviews with other actors yielded data that were richer and more generalizable. Bar owners and managers and NGO representatives were interviewed formally. Their accounts are particularly valuable because they have been in the business a long time and are thus uniquely well-situated to discuss all aspects of the bar scene, including changes over time, the meanings of certain interactional patterns, and the modal characteristics of the MSWs and clients who frequent their premises. For this reason, the paper draws heavily on the accounts of bar staff to provide a broader portrait of MSWs and clients than would be learned from any individual sex worker or client. 
Similarly, the NGO staff we interviewed were uniquely positioned to provide empirical generalisations regarding the young men who work in the bars. Our interviews with these respondents provided key information on broad patterns, such as the kinds of engagement each organisation has with the MSWs and continuities and changes over time in the bar scene. In Berlin, Subway visits MSWs in the bars to discuss safe sex practices; provides information on housing and welfare benefits; and has a few rooms where MSWs can have an occasional shower and meal. Projekt $\breve{S}$ ance in Prague operates as a reintegration programme, offering the men temporary housing, limited job training, and health services, and it also conducts outreach work with street-based MSWs. An informed consent form was provided to respondents at the beginning of the interview translated into German or Czech. Data analysis was organised around the "constant comparison" method that is common in qualitative studies: identifying similarities and differences among the bars both within and between the two cities.

\section{Findings}

Given the prevalence of male bar prostitution in both Berlin and Prague it is surprising that so little research has been conducted in these settings. Although male prostitution in Berlin has been studied in historical perspective (see Evans, 2003) an exhaustive search did not uncover any recent studies of the male bar scene. Similarly in Prague extant research is also limited. Hall (2007) provides a general picture of male bar prostitution in Prague and presents a typology of three types of MSWs who are likely to frequent such bars. Bar-Johnson and Weiss (2015) surveyed 20 male escorts and 20 bar workers in Prague, and found that the bar MSWs were more likely to have troubled family backgrounds and drug/alcohol problems, and they also reported that they sold sex simply in order to survive. These studies are revealing but also need to be supplemented by data on the social ecology and internal organisation of bar prostitution in each 
city.

The legal context differs between the cities. In Berlin, all prostitution is decriminalised and third-party involvement is permitted as long as it does not involve coercion. Hence, brothel, bar, and street sellers conduct business largely unfettered by the local authorities. In the Czech Republic, prostitution is legal but third-party involvement is outlawed. This means that sex workers may freely operate in bars as long as they are not employees or managed by bar staff. To the extent that the latter does occur in some bars, it is against the law albeit rarely enforced. In the 1990s, the police occasionally conducted raids on the bars looking for underage sex workers, but today bar owners and managers generally take their own precautions to exclude underage MSWs from the premises, such as asking to see a passport or national identity card (Bar-Johnson and Weiss, 2015).

\section{Berlin's bars}

Origins and social ecology

Berlin has a long-established "boy bar" scene stretching back as far as the Weimar Republic and which was popularized by the English novelist Christopher Isherwood in the 1930s (Isherwood 1939). The topography of the MSW bar scene in Berlin differs little from Isherwood's day, with four bars clustered close together and located in one of Berlin's established gay districts. The bars form part of a small red-light district: they are in close proximity to each other as well as a number of fetish clubs, a male strip club, a gay cinema where commercial sex also occurs, and several gay bars, bookstores, and shops selling sex paraphernalia. Our observations suggest that the MSW bars are not frequented by young gay German males who are simply out for a drink or who may be looking for sex but not paid sex. The age profile in these bars differs radically between sellers (aged 18-25) and prospective clients (mostly middle-aged males, many of whom are German). 
The neighbourhood surrounding these bars is tidy and fairly tranquil, if not gentrified. These bars differ from more mainstream gay bars in the vicinity in several respects. Compared to bars that do little to disguise the fact that they are gay establishments, the boy bars are more subdued in their external appearance and internal décor. None of them fly the rainbow flag outside the premises and no signage advertises what is available inside or even that they are gay establishments. In two of the bars, access is via an intercom button on the main door that is linked to a CCTV monitor inside. While this may reflect a concern with privacy, it is also related to safety and security: one bar stays open until 5am and another is open 24 hours. The overall appearance of the bars seems to be somewhat utilitarian and the only indicators that the bar might cater to a gay clientele is a small rack containing information about gay Berlin, a few gay pornographic magazines, and sexual health brochures near the bathrooms in each establishment. Although located within a gay district, these bars are in a distinct enclave, perhaps symbolising that male prostitution remains sensitive even by the tolerant standards of Berlin.

\section{Internal bar arrangements}

There is little to distinguish Berlin's rent-boy bars from each other. They are arranged similarly inside; are patronised by the same kinds of clients and sex workers; MSWs provide similar kinds of services to customers; and the bars offer a space where sexual commerce is arranged freelance rather than the sellers being managed by bar staff (i.e., Type 2 bars). The lack of differentiation between the bars and their close proximity to each other means that MSWs can continuously cruise between them in search of potential clients. The MSWs divide their time between the bars, often visiting them in sequence. A MSW may develop a particular preference for working out of a particular bar or he may have been barred from a particular establishment, but generally the modus operandi remains relatively undifferentiated between the various establishments. This involves repeatedly circulating between the various bars in search of clients 
and spending a varying amount of time inside the bars, depending on whether they find a customer to chat with. We observed a small park area near the bars that functions as a kind of haven where MSWs congregate periodically to socialise together and as a respite from the tedium of soliciting clients. On weekends 70 to 100 young men solicit in the bars and in the nearby sex cinema, according to our Subway interviewee.

According to several managers and our observations none of these bars allow sexual activities on the premises and, unlike the situation in Prague discussed below, there is no provision to rent on-site rooms by the hour for such encounters. Instead, a price is negotiated in the bar for a particular service and the client and the MSW then go to a hotel room or apartment. However, we discovered a few instances where sex took place on the premises and in one case with the apparent complicity of the bar staff. In this particular example a client asked the barman for the key to the women's bathroom. After a brief discussion with the MSW they both entered the bathroom and emerged after about 15 minutes. Such activity was atypical, however: these bars function more as places to negotiate sexual commerce, with sex taking place off the premises.

Immigration into Berlin from Eastern Europe has played a key role in shaping the contours of sexual commerce in the city. While MSWs from many nations work in the bars (e.g. Portugal, Russia, Poland) the overwhelming majority are Romanian and Bulgarian immigrants to Berlin, and most come from Roma communities in these countries (Castaneda, 2013). Our Subway respondent explained why:

The attraction of Berlin is that we are rich. Ninety per cent of our clients are gypsy Roma and they have big problems in their country. They are not allowed to go to school, they can't work, and they have no job. They come from towns or villages that have high unemployment, so there is no future for them. They come to Germany: good economy, big money. It is so easy to come to Germany: you don't need a passport, you don't need a visa; 
just an ID and you can come by bus which costs about $€ 80$. And when they come here they feel lost. After a couple of days all the money is gone, and the easiest way to get money is from prostitution.

Consequently, it is young men from Roma communities in Romania and Bulgaria to whom Subway devotes the lion's share of its resources and assistance. This situation has changed considerably in the past ten years with the development of the digital economy:

I have been working here for many years now. About ten years ago we had about 60 to 70 per cent German boys and now it is 2 or 3 per cent. The Germans have moved to the Internet; it is so much easier. If you know the website Planet Romeo, everybody who wants to sell sex uses it. It's so much easier to stay at home and wait for a client. It's not like standing in a bar for hours where nothing is happening. Unlike the Roma boys, most Germans have access to their own place and the Internet so it is very easy for them (interview with Subway official).

Roma communities face severe unemployment and structural discrimination in their home countries, and many Roma males decide to make the trip to Berlin in search of economic opportunities. While Bulgaria and Romania have been members of the EU since 2007, residents of these countries could travel to other EU jurisdictions but could not be legally employed there. ${ }^{3}$ Consequently in Germany, many migrant Romanian and Bulgarian males found themselves increasingly pushed towards the sex economy given the lack of other employment options (cf. Mai, 2009, 2015). According to our Subway interviewee, however, even if these labour market

\footnotetext{
3 These labour market restrictions for Romanians and Bulgarians were lifted in 2014.
} 
restrictions were lifted these young men would have difficulty obtaining employment or integrating into German society. Many young males from Roma backgrounds are functionally illiterate and have had little schooling in their home countries, and the language barrier is an additional obstacle to employment in ordinary jobs (Deutsche Welle, 2012; Mai, 2009). During our observations and conversations with MSWs, few had good command of German; the language of transactional sex was a basic form of English replete with a number of stock phrases relating to what sex acts they were willing to perform. We also met MSWs who had no command of basic English and were thus in an even weaker position to communicate with a potential client.

Observations conducted in the bars indicated that the busiest periods were weekend nights, while at other times there were generally more sex workers present than bar customers. The interactional dynamics inside the bars usually followed a similar pattern, with MSWs sitting around waiting for a potential client to establish contact. The willingness of male sex workers to engage with clients also seemed to be highly variable, which was probably dictated by language skills, and for those who had recently moved to Berlin, uncertainty about what the conduct norms inside the bar entailed. In some cases we witnessed MSWs spending hours sitting alone sipping a cola or a glass of water, making little effort to interact with potential clients. In other cases, some young men were quite "pushy" or aggressive, repeatedly asking bar customers if they wanted "business" (code for sex), which happened to the researchers a few times. Following a negative reply, the sex worker would either linger and persist in asking for a liaison or simply shrug and move on without making any further effort.

Owing to language and communication issues most MSWs tended to socialise among their particular ethnic group and made little or no effort to engage with MSWs beyond this. On the rare occasion that we observed ethnic German sex workers, they were usually by themselves and would spend their time in the immediate vicinity of the bar counter, often chatting with the barman. By contrast, bar staff and the migrant MSWs rarely conversed and when they did it was 
usually brusque or business-like - e.g., telling the MSW to purchase a drink or to move and let a customer have a particular seat.

None of the male sex workers we spoke to in Berlin self-identified as gay, with a few implying that they might be bisexual. However, homosexuality is a fairly peripheral issue for these migrant MSWs. What is more salient are the various ways in which these young males situate their sexuality and engage in same-sex sexual encounters either opportunistically, because of financial need, or because they want to experiment sexually (Ward, 2015; Rosario et al., 2006). Rather than defining their behaviour as gay or bisexual, the young men may take a more utilitarian approach, as has been documented elsewhere (Aggelton, 1999; De Lind van Wijngaarden, 1999; Mai, 2015; Padilla, 2007). One told us, "I fuck for money.” Others rationalised what they were doing in terms of alternative discourses around health and fitness. For instance, a young man from Portugal explained that the only reason he was in Berlin was to make money because his dream of becoming a professional soccer player had been shattered when he was dropped from the youth team of a major club and who joked that 'fucking men keeps me fit'. In the conversations we had with male sex workers, it was clear that the overwhelming majority take an active role in anal sex and a passive role in oral sex and in no case did we elicit any sense that these migrant MSWs provided anything approaching a "boyfriend experience" involving kissing, cuddling, or other expressions of intimacy. The main reason for selling sex was financial and this was the central reason they had migrated to Berlin in the first place. However, financial reasons were also stated as the main reason for getting out of the city. A Romanian sex worker explained:

I'm only doing this shit [prostitution] because I need money to get out of Germany. I hate this country; I hate the people; I hate this fucking bar.... People look at me and think I'm a piece of shit on their shoe. My dream is to go to England, that's where my brother is. He 
works in construction. He tells me you can earn lots of money in England and the people are friendly too. You can make lots of money in England and get your own car and everything.... Maybe someday I will even buy my own house there.

In theory, a migrant MSW in Berlin can make a considerable amount of money: The somewhat rudimentary nature of the services offered by them and the short time it takes to transact an encounter means that on a busy night a male sex worker can serve several clients. At between $€ 30$ and $€ 50$ per transaction, there is the potential to earn as much as $€ 500$ in an evening. In practice, however, the degree to which a migrant MSW can earn money in Berlin's bars depends on a number of variables - age, attractiveness, physique, demeanour - but also their relative newness on the bar scene. In many ways the earning potential of MSWs who operate in these bars is subject to the law of diminishing returns, insofar as the longer they are on the scene the harder it becomes to find clients. Not only do MSWs in Berlin have to compete for clients among their co-workers, but also with newly arrived sex workers who hold a certain novelty appeal. This is important because the stream of potential clients in Berlin appears relatively static and, unlike Prague, is not based around a constantly changing tourist market (Bar-Johnson and Weiss, 2015; BBC, 2013; Dudová, 2011).

In a situation where there are more sex workers than clients - which was generally the case in these bars during the week (with more clients on weekends) - clients can afford to be selective and will typically devote their attention to those MSWs new to the scene. Furthermore, since our observations of MSWs working in these bars suggests that many of them do not engage in those activities that are defined as a "boyfriend experience," there is even less incentive for clients who may want companionship as well as sex to engage with them. Certainly, there is much less intimacy and physical contact (touching, hand-holding, kissing) between MSWs and clients in the Berlin establishments than we observed in Prague. Consequently, the bar scene in Berlin is 
structured around MSWs who rely on a comparatively small client base for income. Some MSWs who had been working in Berlin for a longer time (6 months or longer) told us that their average earnings ranged between $€ 200$ to $€ 300$ per month, an amount that was confirmed by our Subway respondent:

$€ 2000$ is possible [in a month] if you don't spend it all in the slot machines and are clever and handsome with a fresh face. If they are blond and blue-eyed, they can earn a lot of money. The less good you look, the less money you get. But most of our clients do not earn a lot of money.

By European standards, an income of $€ 200-€ 300$ monthly is low, but since many of these young males come from rural villages in Bulgaria and Romania that have high unemployment, this income may be considered significant and considerably higher than what they could earn at home.

\section{Prague's bars}

Origins and social ecology

Compared to the situation in Berlin historically, the bar scene in Prague is a more recent phenomenon. The rise of low-cost flights to Prague in the late 1990s and its relative cheapness as a tourist destination added to its attraction as a key sex tourist venue particularly among European males, and led to the creation of several new erotic bars in the city catering primarily to the gay tourist market (Bunzl, 2000; Hall 2007). During the time our research was conducted, Prague had five commercial premises that facilitated sexual commerce between MSWs and their clients. ${ }^{4}$

\footnotetext{
${ }^{4}$ We focus on the three of the five bars since they nicely reflect the heterogeneity of Prague's bar scene. One of the other bars is in a location remote from the city centre and might be more accurately described as a hotel with a very small bar area where
} 
Male sexual commerce is highly dispersed in Prague. In contrast to Berlin, none of Prague's bars are in the same vicinity and none are situated in areas with a lively night-time economy. As we discuss below, the spatial distancing of these bars both from each other and from the city centre creates some problems for tourists looking for these kinds of places. Consequently, some bars provide a free taxi service to their premises from city centre hotels, while others have expanded their business to provide a range of services and facilities such as the provision of food and accommodation to gay visitors.

In all cases the signage is discreet, with no indication of what occurs within the premises, nor are there any indications from the outside that these establishments cater to a gay clientele. The areas surrounding each bar are residential and tranquil, not dilapidated or criminogenic as in some other cities with erotic businesses. Admission to each bar requires pressing an intercom button on the door. This allows bar staff to screen potential customers and advise novice customers about the nature of the bar's business.

Nor are these bars situated particularly close to other gay establishments, unlike Berlin. Because of the legacy of Communist rule, a concentrated gay commercial sector (bars, clubs, cinemas, saunas) did not emerge in Prague as it did in some other European cities. While the "boy bars" are referenced in gay guides to Prague, our observations indicate that they are distanced from the city's mainstream gay scene and we were told by one bar manager that the local Gay Pride organisation refuses to endorse his bar's activities. All but one of the establishments in Prague cater to a mainly tourist market; the clientele is comprised of middle-aged and older men from Western Europe and the United States (Bar-Johnson and Weiss, 2015; cf. Darley, 2009). Sex tourism is thus more prevalent in Prague's bars than in their Berlin counterparts (Bunzl, 2000). At the time the research was conducted, foreigners owned all of these establishments, though Czech

MSWs operate. Another bar had recently opened; when we visited, few people were there and it was fairly quiet. 
staff were employed in them. Indeed, the overall commercial organisation of the bar sector is much more diverse in Prague than in Berlin. For example, the co-owner of one such establishment - Man's World - is also a well-known producer of Czech gay pornography and is the outright owner of a similar bar in Amsterdam (interview with bar manager).

Internal bar arrangements

While Berlin is notable for its lack of differentiation among the bars and the sex-workers who solicit in them, the situation in Prague is characterized by greater heterogeneity both in the bars' internal social order as well as among the MSWs (age, appearance, services). One noticeable difference concerns MSWs' spatial mobility. Most MSWs in Prague work out of a single bar rather than moving between them, partly because the bars are dispersed throughout the city, which makes bar-hopping logistically inconvenient. In addition, moving between these bars is discouraged by management. We were told by several MSWs that the management at two establishments requires them to be in the bar at certain times and they are not allowed to leave the bar during peak business hours on weekend nights (11pm-2am). There are two related reasons for this: to ensure that MSWs are always on the premises to attract clients but also to fraternise with clients in order to keep them spending money on drinks. There do not appear to be any such restrictions in Berlin's bars; the MSWs come and go as they please.

Club Prince is the most popular nightclub in Prague for male commercial sex and is located outside the city centre in a mixed residential and business district. On a busy weekend night there can be as many as $30 \mathrm{MSWs}$ and 100 customers on the premises. While Club Prince is primarily a nightclub (open 6pm to 4am) the owner also operates a smaller public bar 100 metres away that is open throughout the day. Commercial sex is transacted in both the bar and the nightclub, and MSWs tend to congregate in the bar during the day and relocate to the club in the evening. During weekend nights the nightclub also employs male strippers who wander around in their underwear 
asking for donations and also solicit sexual transactions. Club Prince has a reputation as a place where young MSWs (18-21) operate, and appears to cater specifically to those older men who prefer younger MSWS. While this particular establishment was previously raided by the police and closed down following allegations of under-age prostitution and drugs, a current employee told us that the new owner does not tolerate drugs on the premises and that anyone caught using or dealing will be banned. Furthermore, all MSWs have to show ID to bar staff to prove that they are of legal age to sell sex. Since this bar is in a fairly remote location, it also provides customers with accommodation, food, a taxi service, and rooms for rent by the hour. The MSW and his client negotiate a price and can retire to a room above the bar area to transact whatever business has been agreed. Payment for the room is made to the bar directly when the customer leaves. Beds in dormitory-style rooms are also provided to MSWs for $€ 7$ per night if they have no other accommodation, which also means that there is a steady stream of MSWs available on the premises.

Another popular bar, Paradise, is located somewhat closer to the main tourist drag and actively markets itself as a venue featuring upscale MSWs. Paradise charges an admission fee of Kc200 (€7) and its drinks are considerably more expensive than at Club Prince or Man's World (discussed below). Like Club Prince, Paradise is geared primarily to gay tourists visiting the city, although it is somewhat more accessible because it is located closer than the other bars to hotels in the city centre. Paradise features male strippers on weekends and some of its MSWs have also performed in gay erotic videos for Czech and Slovakian pornography companies headquartered in Prague (interview, bar manager). However, it is difficult to ascertain the trajectory here: whether involvement in gay pornography typically leads to prostitution or whether the latter provides the initial contacts for entry into the porn industry. Nevertheless, we were not aware of any overlap between gay pornography and commercial sex in Berlin's bars.

In all of Prague's bars there was a steady stream of clients from Western Europe and the 
United States. Because of this, the earning potential of MSWs in Prague is considerably higher than for their counterparts in Berlin. The amount of money that can be charged for a commercial sex transaction also varies with the tier of the establishment and the attractiveness of the sex workers who operate there. Unlike the situation in Berlin where there was little heterogeneity among MSWs between the various establishments, the situation in Prague is much more varied with different bars catering to a range of client tastes, such as "frat boy," athlete, "twink," "straight acting," and so on. As a MSW at Club Prince told us:

It depends what you are looking for, and the price depends on how the boy looks, whether he is a young looking or straight acting. Most of the boys who work here are young and they attract men who like that. In another bar it would be different. I could take you to a bar where the boys are older and more athletic, more masculine. Generally clients like a type of boy and will stay in the bar until they meet someone they like.

Club Prince generally has younger MSWs (18-21) who charge Kc2000-4000 (€70-150) per hour depending on the service. Their counterparts in Paradise are slightly older and can often charge a premium because of their athletic build and porn star looks. The hourly rate for sex in Paradise is between Kc3000-6000 (€100-200) however we were informed by a bar manager that in some cases a MSW will spend the night with a client for substantially larger amounts of money.

In both these establishments no money changes hands at the bar for drinks and the prices are geared to a tourist rather than a local market. On entry, MSWs and customers are issued with a drinks card and beverages are recorded on this throughout their time in the bar. This card is then handed to a cashier upon leaving. Protocol in both establishments dictates that the client always picks up the drinks tab of the MSW he has chosen to leave with and given the expensive nature of 
the drinks the amount can come as a surprise to the client. In one case, we witnessed a heated argument between an American customer and a member of the bar staff about what the former perceived as the exorbitant cost of the MSW's drinks tab. These bars derive a significant proportion of their income from the sale of alcoholic and non-alcoholic beverages and one customer told us that it would not be unusual for him to spend around $€ 100$ on drinks during a night out.

Like the male tourist clients of female sex workers in developing countries, who are often attracted to these settings because of their racialised constructions of the women as exotic or hypersexual, at least some sex tourists who travel to places where male sex workers operate have similar eroticizing preconceptions about the men who sell sex in those places. Such Othering has been documented in the Caribbean (Padilla, 2007), Brazil (Mitchell, 2011), Mexico (Mendoza, 2013), and Thailand (De Lind van Wijngaarden, 1999). Based on our field observations in Prague, by contrast, the vast majority of both customers and sex workers in the bars were Caucasian Instead of racial eroticisation, the central attraction that Prague's bar workers represented was a different kind of Othering: the variety offered by a sexual liaison with a young foreign male, an experience unlike what they would have at home. In other words, some men may be uniquely attracted to young foreign men, albeit European men - a kind of dividend that they would not experience by an encounter with a young man in their home country. It is also the case that the notion of situational sexuality can apply to clients as well as MSWs, and some clients may be more comfortable buying sex outside their home country fearing detection at home. For these men, anonymity is the driving force, not Othering. Anonymity in a foreign destination is a major motive among men who buy sex from female sex workers as well.

Another of these bars - Man's World - is situated some distance from the gay tourist circuit in a mixed business/residential suburb. This bar charges an admission fee and is open 24 hours. According to the bar manager, 70 per cent of customers in Man's World are Czech and the 
remainder tourists, which means that the prices for drinks are rather lower than in the touristoriented bars. Like the other two bars, Man's World has male strippers who mingle with the customers and seek donations for their performances. The bar also provides a room with a bed and shower facilities that can be rented by the hour (Kc400 or $€ 15)$ for MSWs to transact business with clients; the manager estimates that this occurs around 4 to 5 times per week. During our visits to Man's World we noted that there were always more customers than MSWs and, according to the manager the relative isolation of the bar and the lack of tourist trade means that it has some difficulty in attracting sex workers to the premises and some that it did attract were suspected of petty criminality such as pickpocketing from clients. Indeed, at the time the research was conducted the bar was considering banning MSWs from the premises entirely. However, during a follow-up visit several months later (December 2013) the manager stated that he had reconsidered the issue and was now planning to pay several of the "better quality" MSWs to be permanently present on the premises: they would be paid a retainer by the bar and would be allowed to keep all the income they earned from clients.

The interactional dynamics within the bars themselves also differs considerably from what we observed in Berlin. While MSWs in Berlin could often be found just sitting around with little effort to engage with clients, those in Prague were much more enterprising: many could be observed chatting and having a drink with a prospective client. This level of engagement is a function of the language skills of these young men and the fact that they and potential clients shared a lingua franca: English. We also observed displays of intimacy and affection - holding hands, cuddling, kissing - between MSWs and prospective clients that did not occur in Berlin. The bar workers in Prague therefore come closer to offering a more comprehensive "boyfriend experience" than do their counterparts in Berlin. One bar manager who has over ten years of experience with Prague's bar scene stated that around half of the young men working in Club Prince and Paradise would self-identify as gay, though he also noted that the issue of sexuality 
was somewhat fluid in the Czech Republic and some heterosexuals work in the bars as well. Some young Czech MSWs readily admitted their sexual orientation and emphasised the overlap between their sexual behaviour at work and more generally. As a Czech MSW suggested:

I do this because I can get money, which helps me with my studies at university. But I also like sex.... For me having sex with a man is no big deal because I only ever have sex with men anyway.... I'm gay and will tell anybody that.... So it's getting paid for something I like doing.

We noted in the Berlin case that the overwhelming majority of MSWs were economic migrants. Migration also plays a role in Prague, but tends to be internal rather than international. According to our respondents as well as our own observations, the vast majority of MSWs in these bars are Czech with a smaller number from Slovakia (confirmed by Bar-Johnson and Weiss [2015]). Our informant at Projekt Šance told us that Prague's street sector, by contrast, was largely comprised of young Roma males from the Czech Republic and eastern Slovakia. Thus, the bar sector in Prague is the inverse of what is found in Berlin: ethnic Czechs work in Prague's bars and Czech and Slovakian Roma work on the streets.

Despite the economic progress resulting from the country's EU admission in 2004, the eastern part of the Czech Republic remains relatively underdeveloped, with continuing industrial decline and high unemployment. Consequently, there are few opportunities available for young people from this part of the country. The economic opportunities that Prague offers serve as a powerful pull factor encouraging migration into the city. Some of these young men inevitably gravitate to the commercial sex sector, which can pay considerably more than the average Czech wage for someone without skills or qualifications (approximately $€ 480$ per month). As one Czech MSW explained: 
I come from a small town near the border with Slovakia.... There is nothing happening for young people, there are no jobs, and the situation is very bad. Anyone that wants to earn money moves out of the town as quickly as they can; that's why I am in Prague.... I'm trying to earn money.

As noted above, a quantitative study (Bar-Johnson and Weiss, 2015) found that a number of MSWs who worked in Prague's bars came from dysfunctional family backgrounds, had alcohol or drug problems, and sold sex simply for survival purposes. In addition, one-quarter of the bar workers were homeless at the time they were surveyed, and most stated that they engaged in this work out of economic desperation; only 30 per cent stated that they were satisfied with their work. We found some supporting evidence during our interviews and observations, but also concluded that the situation is perhaps more nuanced. At no stage did we observe MSWs consuming drugs either in or near the bars, nor did we witness any heavy alcohol consumption, with Red Bull appearing to be the beverage of choice. Sobriety is necessary for them to perform their work but is also a risk-reduction tactic, to avoid violence or other abuse from a client.

Other studies of male sex work have documented the various attitudes that MSWs have to their job (Calhoun and Weaver, 1996; Dorais, 2005; Ellison, 2016) and as we noted above, some MSWs view their job instrumentally as a way of saving money in order to relocate out of Berlin or to finance university studies in Prague. A bar manager who has extensive knowledge of the male sex work scene in Prague stated that some MSWs can earn a considerable amount of money and eventually save enough to rent an apartment, enter another line of work, enrol in college, or start escorting by advertising on the Internet. He also noted, however, that some MSWs get caught up in "a party scene" and spend money as fast as they earn it - partying, gambling, or consuming illicit drugs such as Pervitin, a methamphetamine (see also Bar-Johnson and Weiss, 2015). 
However, this bar manager stressed that the consumption of illicit substances was hardly the preserve of sex workers and was in fact "a normal part of the social life of young people whoever and wherever they might be." When asked about the life-course of a MSW in Prague, the manager explained that "the working life of a rent boy is actually very short. Once they hit 25 or at the most 28, they have had it as far as the bars go." In this scenario, the only option for a MSW who wishes to continue selling sex is that he is retained by a number of regular clients (Hall 2007), while some may move to Internet-facilitated indoor commercial sex if they can afford to rent an apartment. But the length of time that a young man can sell sex is typically finite given that the market for older male sex workers is fairly small. Given the transient nature of much male sex work and the fact that those who operate from bars are relatively anonymous, almost nothing is known bout their post-bar trajectory. As another manager remarked, "What happens to a Club Prince boy is one of life's great unanswered questions." He went on to say that some may find alternative employment and "simply drift off the radar," but others "end up getting addicted to Pervitin and will work the park or public toilets." Indeed, we found that Prague lags behind Berlin in its provision of support services to male sex workers - particularly those who work inside the bars. The mainly Roma males who work on the streets or near the main train station in Prague, not the bar workers, are the main clientele of the NGO that engages in outreach services for sex workers (interview with Projekt Šance).

\section{Conclusion}

This study has documented and compared the ecological contexts and social organisation of male bar prostitution in Berlin and Prague. Both structural and micro-level processes interact to create distinctive topographies in each city. Structurally, migration plays a key role in the landscape of sexual commerce in Berlin and Prague, but its manifestation reflects considerable contrasts. Romanians and Bulgarians form the bulk of MSWs who operate in Berlin's bars and 
who have moved to the city in search of better economic opportunities. We found no evidence that international migration was a significant facet of male bar work in Prague. Prague's bar workers are invariably either locals or labour migrants from outlying parts of the Czech Republic or Slovakia, seeking to exploit the economic opportunities that Prague has to offer.

Micro-level processes reflect significant variation in the nature of commercial sex undertaken in the two cities. We found that in Berlin neither the sex workers nor the clients vary from place to place, and social interaction within the bars is strikingly similar in terms of how MSWs engage with staff and with clients and in the services they provide. Berlin's bars differ slightly in terms of size, décor, and other internal arrangements, but such differences are not significant enough to affect the social order of these bars.

Prague stands in stark contrast to Berlin. First, Prague's bars have evolved to meet a diverse range of client tastes. They vary in the MSWs' ages and appearance and in whether stage performances occur, whether sex toys and other accoutrements are available for purchase, and in whether sex is available on the premises. Berlin's bars offer none of these attractions. Second, the nationality background of most bar workers - migrants from Romania and Bulgaria in Berlin, Czech nationals in Prague - has a major impact on the amount and quality of social interaction in the bars, with Berlin's largely confined to negotiating the sexual act and Prague's being more varied and expansive. Prague's bar workers readily engage in extended conversations with customers and offer a sense of companionship that is missing from the repertoire of the migrant MSWs who work in Berlin's bars, where linguistic and cultural differences pre-empt extended or intimate conversations. In other words, MSWs in Prague's bars are more willing and able to provide a "boyfriend experience" to their customers. Third, to a greater extent than in Berlin, Prague's bar scene is influenced by the city's status as a major European destination for male sex tourism. All but one of Prague's bars (Man's World) derive income almost entirely from the gay tourist market, and some of the bars offer accommodation and other facilities to tourists. By 
contrast, many of the customers in Berlin's bars are German nationals. Whereas male bar prostitution has certain core similarities in both cities, the participants in Prague's bars can be considered the inverse of Berlin's: in Prague many of the clients are foreign tourists and in Berlin the sex workers are foreign migrants. Finally, the commercial organisation of the bar scene in Prague is more heterogeneous than in Berlin: (1) Prague's bars are owned by foreign nationals from outside the jurisdiction, while those in Berlin are owned by German locals and (2) some Czech bar workers in Prague also work in the gay pornography sector, which is non-existent among Berlin's migrant bar workers.

The MSW bar sector in Berlin and Prague has evolved over the years to reflect changes in the landscape of male sexual commerce, though for a considerably longer period in Berlin. As these bars continue to serve a particular segment of the commercial sex market, it is likely that these bars will continue to be a significant component of sexual commerce in both cities for the foreseeable future.

\section{Acknowledgements}

We would like to thank the anonymous reviewers for their insightful comments on an earlier draft of this paper. Thanks also to those MSWs, bar managers, clients and NGO representatives in Berlin and Prague who agreed to be interviewed for the study on which this paper is based. Special thanks also to Susann Huschke and Igor Barak who were extremely diligent and helpful in providing research assistance in Berlin and Prague respectively.

\section{References}

Aggleton P (ed.) (1999) Men Who Sell Sex. Philadelphia: Temple University Press.

Atkins M and Laing M (2012) Walking the beat and doing business: Exploring spaces of male sex work and public sex. Sexualities 15 (5/6): 622-642.

Bar-Johnson M and Weiss P (2015) A comparison of male sex workers in Prague: Internet escorts versus men who work in specialized bars and clubs. Journal of Sex Research 52 (3): 338-346. 
BBC [British Broadcasting Corporation] (2013) Sex, stags, and Prague. October 7, BBC 3.

Bunzl M (2000) The Prague experience: Gay male sex tourism and the neocolonial invention of an embodied border. In: Berdahl D, Bunzl M, and Lampland M (eds), Altering States: Ethnographies of Transition in Eastern Europe and the Former Soviet Union. Ann Arbor: University of Michigan Press, pp. 70-95.

Calhoun T and Weaver G (1996) Rational decision-making among male street prostitutes. Deviant Behaviour 17 (2): 209-227.

Castaneda H (2013) Structural vulnerability and access to medical care among migrant street-based male sex workers in Germany. Social Science and Medicine 84 (1): 94-101.

Darley M (2009) Prostitution in nightclubs in border areas of the Czech Republic. Revue Francaise de Sociologie 50: 95-124.

Davies P and Feldman R (1999) Selling sex in Cardiff and London. In: Aggleton P (ed), Men Who Sell Sex. Philadelphia, PA: Temple University Press, pp. 1-22.

De Lind van Wijngaarden J (1999) Between money, morality, and masculinity: Bar-based male sex work in Chiang Mai. Journal of Gay \& Lesbian Social Services 9 (2/3): 193-218.

Dennis J (2008) Women are victims, men make choices: The invisibility of men and boys in the global sex trade. Gender Issues 25 (1): 11-25.

Dorais M (2005) Rent Boys: The World of Male Sex Trade Workers. Montreal: McGill University Press.

Dudová R (2011) Sex tourism in the Czech Republic. Socioweb 7-8, accessed June 3, 2015 http://www.socioweb.cz/index.php?disp=teorie\&shw=475\&lst=115male

Ellison G (2016) Drifters, party boys, and incumbents: The life patterns of male street-based sex workers. Sociology DOI: 10.1177/0038038516676768 
Ellison G and Weitzer R (2016) The dynamics of male and female street prostitution in Manchester, England. Men \& Masculinities DOI: 10.1177/1097184X15625318

Evans JV, (2003) Bahnhof Boys: Policing Male Prostitution in Post-Nazi Berlin. Journal of the History of Sexuality, 12, (4) Oct.,605-636

El-Bassel N (2000) Sex trading and psychological distress in a street-based sample of lowincome urban men. Journal of Psychoactive Drugs 32 (3): 259-267.

Hall T (2007) Rent-boys, barflies, and kept men: Men involved in sex with men for compensation in Prague. Sexualities 10 (4): 457-472.

Isherwood C (1939) Goodbye to Berlin. London: Hogarth Press.

Kishindo P (1995) Sexual behavior in the face of risk: The case of bar girls in Malawi's major cities. Health Transition Review 5: 153-160.

Koken J, Bimbi D, and Parsons J (2010) Male and female escorts: A comparative analysis. In: Weitzer R (ed), Sex for Sale. New York: Routledge, pp. 205-232.

Lankenau S, Clatts M, Welle D, Goldsamt L, and Gwadz M (2005) Street careers: Homelessness, drug use, and sex work among young men who have sex with men. International Journal of Drug Policy 16 (1): 10-18.

Linz D (2004) An examination of the assumption that adult businesses are associated with crime in surrounding areas. Law and Society Review 38 (1): 69-104.

Mai N (2009) Migrant Workers in the UK Sex Industry. London: London Metropolitan University.

Mai N (2015) Surfing liquid modernity: Albanian and Romanian male sex workers in Europe. In: Aggleton P and Parker R (eds), Men Who Sell Sex: Global Perspectives. New York: 
Routledge, pp. 27-41.

Mendoza C (2013) Beyond sex tourism: Gay tourists and male sex workers in Puerto Vallarta. International Journal of Tourism Research 15 (2): 122-137.

Minichiello V (2001) Male sex workers in three Australian cities. Journal of Homosexuality 42 (1): 29-51.

Mitchell G (2011) Turbo consumers in paradise: Tourism, civil rights, and Brazil's gay sex industry. American Ethnologist 38 (4): 666-682.

Padilla M (2007) Caribbean Pleasure Industry. Chicago: University of Chicago Press.

Pittman D (1971) The male house of prostitution. Transaction 8: 21-27.

Prior J and Crofts P (2012) Effects of sex premises on neighbourhoods. New Zealand Geographer 68 (2): 130-140.

Rosario M, Schrimshaw E, Hunter J, and Braun L (2006) Sexual identity development among lesbian, gay, and bisexual youths: Consistency and change over time. Journal of Sex Research, 43 (1): 46-58.

Salamon E (1989) The homosexual escort agency. British Journal of Sociology 40 (1): 1-21.

Schifter J and Aggleton P (1999) Cacherismo in a San Jose brothel: Aspects of male sex work in Costa Rica. In: Aggleton P (ed), Men Who Sell Sex. Philadelphia, PA: Temple University Press, pp. 141-158.

Smith M, Grov C, and Seal D (2008) Agency-based male sex work. Journal of Men's Studies 16 (2): 193-210.

Steinfatt T (2002) Working at the Bar: Sex Work and Health Communication in Thailand. Westport, CT: Ablex. 
Storer G (1999) Bar talk: Thai male sex workers and their customers. In: Aggleton P (ed), Men Who Sell Sex. Philadelphia, PA: Temple University Press, pp. 223-240.

Takeyama A (2005) Commodified romance in a Tokyo host club. In: McLelland M and Dasgupta R (eds), Genders, Transgenders, and Sexualities in Japan. New York: Routledge, pp. 200-215.

Trotter H (2008) Sugar Girls and Seamen: Dockside Prostitution in South Africa. Johannesburg: Jacana.

Uy J, Parsons J, Bimbi D, Koken J, Halkitis A, and Perry N (2007) Gay and bisexual male escorts who advertise on the internet. International Journal of Men's Health 3 (1): 11-26

Ward J (2015) Not Gay: Sex between Straight White Men. New York: NYU Press.

Weitzer R (2012) Legalizing Prostitution: From Illicit Vice to Lawful Business. New York: New York University Press.

Weitzer R (2014) The social ecology of red-light districts: A comparison of Antwerp and Brussels. Urban Affairs Review 50 (5): 702-730.

Weitzer R and Boels D (2015) Ghent's red-light district in comparative perspective. Sexuality Research and Social Policy 12 (3): 248-260.

West D (1993) Male Prostitution. Binghamton, NY: Hayworth.

Zheng T (2009) Red lights: The Lives of Sex Workers in Postsocialist China. Minneapolis: University of Minnesota Press.

\section{Graham Ellison}


Ronald Weitzer is a professor of sociology at George Washington University. He has published extensively on sex work, including his books Sex For Sale: Prostitution, Pornography, and the Sex Industry (2000 and 2010) and Legalizing Prostitution: From Illicit Vice to Lawful Business (2012). In 2014 he co-edited a volume on human trafficking for the Annals of the American Academy of Political and Social Science.

\section{Notes}

